J. Clin. Chem. Clin. Biochem.

Vol. 16, 1978, pp. 669-674

\title{
Improved Preparation and Structural Elucidation of the Tryptophan Cleavage Reagent 2-(2'-Nitro- phenylsulfenyl)-3-methyl-3-bromoindolenine (BNPS-skatole)
}

\author{
By H.J. Zeitler and M. Eulitz \\ Gesellschaft für Strahlen- und Umweltforschung mbH, Abteilung für Klinische Hämatologie, München
}

(Received March 23/July 27, 1978)

Summary: Methods are described for a high yield preparation (overall yield $>90 \%$ ) of analytically pure 2-(2'-nitrophenylsulfenyl)-3-methyl-3-bromoindolenine (BNPS-skatole). The chromatographic and spectroscopic data are given. The yield of tryptophan cleavage in proteins is considerably dependent on the degree of purity of the BNPS-skatole.

\section{Reindarstellung und Strukturklärung des Tryptophan-spaltenden Reagenz 2-(2'-Nitrophenylsulfenyl)-3-methyl-3-bromindolenin (BNPS-Skatol)}

Zusammenfassung: Es wird eine Methode zur Darstellung von analytisch reinem 2-( ${ }^{\prime}$-Nitrophenylsulfenyl)-3methyl-3-bromindolenin (BNPS-Skatol) in hoher Ausbeute (Gesamtausbeute >90\%) beschrieben. Die IndoleninStruktur ergibt sich eindeutig aus den spektroskopischen Daten, vor allem aus dem ${ }^{13} \mathrm{C}$-NMR-Spektrum. Die Ausbeute der Tryptophan-Spaltung in Proteinen ist neben verschiedenen Reaktionsbedingungen und der Proteinstruktur (Aminosäuren in Tryptophan-Nachbarschaft) wesentlich von der durch Dünnschichtchromatographie leicht zu prüfenden Reinheit des BNPS-Skatols abhängig.

\section{Introduction}

A simple disc-electrophoretic evaluation of the number of peptide fragments after cleavage at the tryptophan positions can be used for the determination of the tryptophan content in clinically interesting peptides or proteins (analysis of inborn errors; sequence determination). A selective cleavage reagent for this purpose is BNPS-skatole.

The ultravioiet, infrared, proton nuclear magnetic resonance and mass spectra of BNPS-skatole do not enable conclusive differentiation between the 3-bromoindolenine and the equally possible N-bromoindole structure. We havé prôduced evideñce in favour of the indolenine structure by means of ${ }^{13} \mathrm{C}$ nuclear magnetic resonance. Column and thin layer chromātographic behaviour of the nitrophenylated and brominated skatole derivatives were studied. In the cleavage of protein at tryptophan positions, yields of up to $85 \%$ were obtained.

For the modification of histidine, tyrosine and tryptophan in proteins, and for the cleavage of the peptide chains at these positions, various $\mathbf{N}$-halogenated compounds (1-9) in acidic media are used: N-bromosuccinimide (7), tribromocresol (10), N-chlorobenzo- triazole (11) and 2-(2'-nitrophenylsulfenyl)-3-methyl3-bromoindolenine (BNPS-skatole), $(12,13)$. In contrast to the extremely reactive reagent $\mathrm{N}$-bromosuccinimide, BNPS-skatole is a relatively mild and selective oxidising agent which, through the splitting off of positive bromine, selectively attacks at the tryptophan site (cleavage of the "C-peptide" bond) according to the reaction scheme I-IV. This is accompanied by the loss of the tryptophan absorption at $280 \mathrm{~nm}$ and the appearance of a new absorption of the assumed 2-amino-3-(2'-oxo-3'-hydroxyindoline)propionic acid lactone (IV) at 240-250 nm $(14,15)$. As prerequisites for this reaction on proteins, cysteine, which is also oxidised by BNPS-skatole to cystine and to cysteic acid (12), must be protected by aminoethylation or carboxymethylation. Tyrosine, if it is not already protected by 0 -dinitrophenylation or 0 -acylation, must also be protected by the addition of phenol (16). The possibility of modifying or respectively cleaving a peptide chain at tryptophan sites. with BNPS-skatole is dependent on the reaction time and on the quantity of reagent $(13,17,18)$. It was shown during investigations in this laboratory that the yield in protein cleavage, and the occurrence of secondary reactions are also dependent to a considerable extent on the purity of the cleavage reagent employed. 


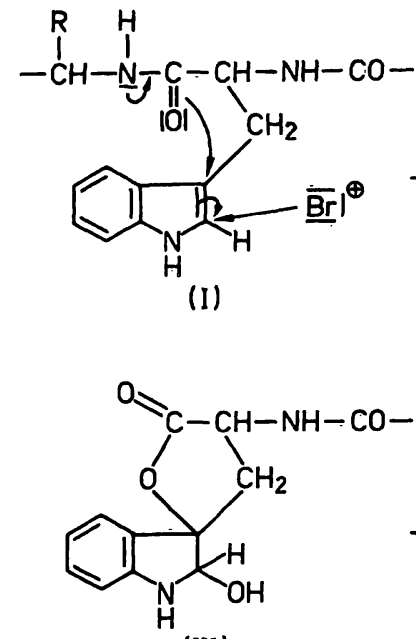

(III)
(BNPS-Skatole)<smiles>[R]C(C)NC(=O)C1CC2(CC1NC(C)=O)Nc1ccccc1O2</smiles>

(II)<smiles>CC(=O)NC1CC2(CC1=O)OC(=O)Nc1ccccc12</smiles>

(IV)

\section{Materials and Methods}

BNPS-skatole was from Pierce (Pierce Eurochemie, Rotterdam), $\mathrm{N}$-Bromosuccinimide, 3-methylindole (skatole) and silica gel for column chromatography $(0.2-0.5 \mathrm{~mm}, 30-70$ mesh ASTM) were from Merck, D-6100 Darmstadt; silica gel $(0.05-0.2 \mathrm{~mm}$ ) and aluminium oxide (Super I) for column chromatography were from Woelm, D-3440 Eschwege; silica thin layer chromatography plates (precoated; Polygram SIL G/UV) were from Macherey and Nagel, D-5160 Düren; 2-nitrophenylsulfenyl chloride was from Fluka, D-7910 NeuUlm; all solvents used were of analytical grade. The infrared and the ultraviolet spectra were recorded with a Philips-Unicam SP. $200 \mathrm{G}$ and with a SP. $800 \mathrm{~B}$, respectively; the mass spectra were made with a Varian $\mathrm{CH} 7 \mathrm{~A}$, the proton nuclear magnetic resonance spectra ( $10 \%$ solution in $\mathrm{CDCl}_{3}$ ) with a Varian HA-100 and the ${ }^{13} \mathrm{C}$ NMR spectra (10\% solution in $\mathrm{CDCl}_{3}$ ) with a Bruker WH 90. The melting points (Leitz MikroskopHeiztisch, type 350 ) were not corrected.

\section{N-Brom osuccinimide}

Since the purification of $\mathrm{N}$-bromosuccinimide by a threefold crystallization from hot water (9-fold volume; yield $43 \%$ ) was unsuccessful (see "Results and Discussion"), we used organic solvents for the recrystallization: carbon tetrachloride (425-fold volume; yield $74 \%$ ), benzene ( 30 -fold volume; yield $66 \%$ ) or anhydrous nitroethane (dried with anhydrous sodium sulfate and filtered over neutral aluminium oxide; 2 .8-fold volume; yield $85 \%$ ).

\section{2-(2'-Nitrophenylsulfenyl)-3-methy lindole}

(NPS-skatole)

\section{Preparation method I}

A suspension of equimolar quantities $(0.19 \mathrm{~mol})$ of 3-methylind ole (skatole) and 2-nitrophenylsulfenyl chloride was reacted in glacial acetic acid $(200 \mathrm{ml})$ for two hours at room temperature. The brown reaction mixture was concentrated under vacuum in a rotary evaporator and the dark brown NPS-skatole filtered off and air-dried. The NPS-skatole precipitated again as brown powder (fraction 1) from the hot solution (13) in $650 \mathrm{ml} / 1$ acetic acid (approx. 20-fold volume).

\section{Preparation method II}

$25 \mathrm{~g}$ of skatole $(0.19 \mathrm{~mol})$ in $100 \mathrm{ml}$ glacial ace tic acid were dropped whilst stirring (magnetic stirrer) into a warm solution of $36.3 \mathrm{~g}(0.19 \mathrm{~mol})$ of 2-nitrophenylsulfenyl chloride in $750 \mathrm{ml}$ of glacial acetic acid and stirred for 1.5 hours at room temperature. The colour of the solution turned from yellow to dark olive-brown. After distilling off the glacial acetic acid in vacuo at $30^{\circ} \mathrm{C}$ in a rotary evaporator, the residue was dissolved in $80 \mathrm{ml}$ of benzene and the benzene evaporated in vacuo to dryness (fraction 2; yield $99.6 \%$ ).

\section{Column chromatographic purification}

Each of the NPS-skatole fractions $(1 ; 2)$ were dissolved in the 8-fold quantity of warm benzene and the olive-green solution was filtered through a silica gel column $(25 \times 1000 \mathrm{~mm}$; filling height $250 \mathrm{~mm}$; silica gel of 30-70 mesh, made into a slurry with benzene) using benzene as eluant. After evaporation of the benzene in vacuo the NPS-skatole was obtained from the orange-yellow main zone as a dark yellow residue. Yield: $51.01 \mathrm{~g} \mathrm{(94.1 \% ;} \mathrm{fraction} \mathrm{1)} \mathrm{and} 53.7 \mathrm{~g}(99.2 \%$; fraction 2). The rechromatographed NPS-skatole (column dimension $25 \times 1000 \mathrm{~mm}$; gel bed $100 \mathrm{~mm}$ of silica gel/ grain size $0.05-0.2 \mathrm{~mm}$; benzene as eluant; yield quantitative) showed only three remaining very weak secondary spots on the thin layer chromatographic control (see below). NPSskatole can be crystallized from a 7-to 8-fold quantity of methanol (yield $81 \%$ ), a 67 -fold volume of $800 \mathrm{ml} / \mathrm{l}$ methanol (yield $68 \%$ ), a 108 -fold volume of ligroin (b. p. $80-120^{\circ} \mathrm{C}$; yield $85 \%$ ), an 18-fold volume of $750 \mathrm{ml} / 1$ acetic acid (yield $93 \%$ ) or a 21 -fold volume of $650 \mathrm{ml} / \mathrm{l}$ acetic acid (y ield $97 \%$ ). When crystallizing from aqueous acetic acid the solution of NPS-skatole in boiling glacial acetic acid is mixed with the calculated quantity of boiling water and the filtered solution, after cooling to ca. $70^{\circ} \mathrm{C}$, is seeded whilst stirring (if the solution is not seeded a red oil forms in part, this being difficult to crystallize). The solution is then cooled to about $0^{\circ} \mathrm{C}$ and after an hour the crystalline precipitate is filtered off and airdried. After the second crystallization the NPS-skatole appeared uniform in thin layer chromatography (silica gel with fluorescent indicator; uv detection at $254 \mathrm{~nm}$; solvent: benzene/ligroin, volumes $3+1) ; \mathbf{R}_{\mathbf{f}}$ (skatole) $=0.60 ; \ddot{\mathbf{R}}_{\mathbf{f}}($ NPS-skatole) $=0.53$ (fig. 1). Melting point $142.5-143^{\circ} \mathrm{C}$ (lit. $(13,19): 125-127^{\circ} \mathrm{C}$ ).

2-(2'-Nitrophenylsulfenyl)-3-methyl-3-brom oind olenine (BNPS-skatole, V)

\section{Preparation method I}

The precipitate brought down with $300 \mathrm{ml}$ water from a solution containing equimolar quantities (13) of N-bromosuccinimide and NPS-skatole $(10 \mathrm{mmol})$ in $100 \mathrm{ml}$ of glacial ace tic acid after 20 minutes' reaction at $20^{\circ} \mathrm{C}$ was extracted with benzene and the dried benzene extract evaporated $\left(30^{\circ} \mathrm{C}\right)$ in vacuo. Since the oily residue could not be crystallized from petroleum ether, it was purified by means of column chromatography (as described in "method III"); the benzene eluate residue crystallized on rubbing with petroleum ether (yield $76 \%$ ); the dark brown zone at the top of the column was discarded. According to the thin layer chromatography (as described for NPS skatole) the BNPS-skatole contained three impurities, one of which was identified as NPS-skatole. After a second column chromatography the impurities were only weakly in evidence.

\section{Preparation method II}

Each $10 \mathrm{mmol}$ NPS-skatole was reacted in glacial acetic acid with $15 \mathrm{mmol}$ or respectively $20 \mathrm{mmol}$ of $\mathrm{N}$-bromosuccinimide 


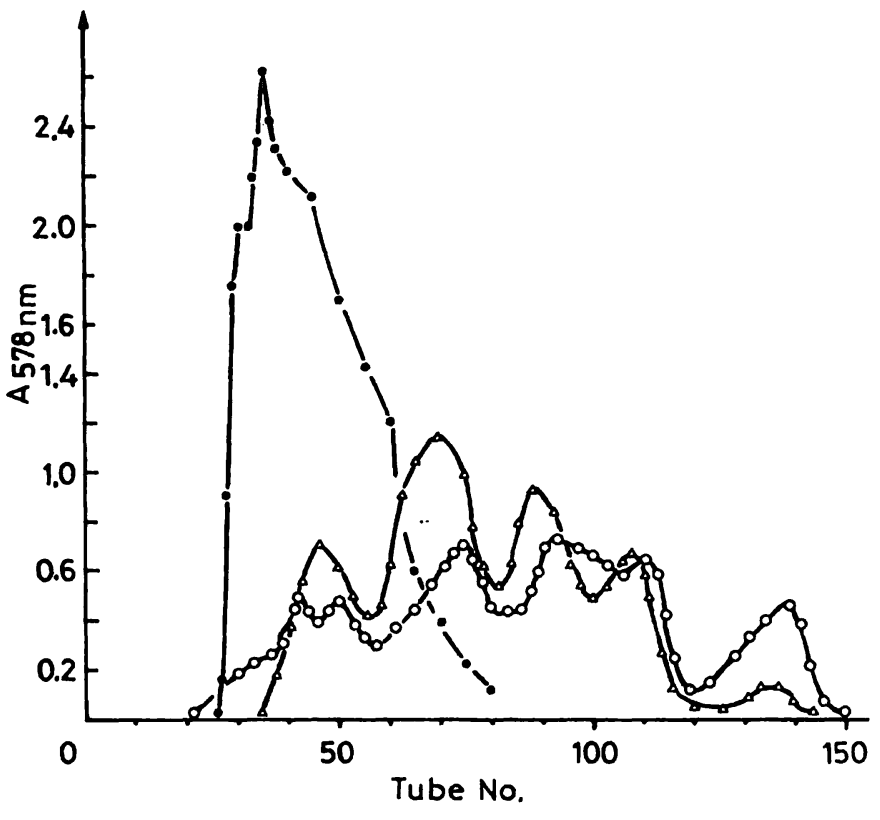

Fig. 1. The figure shows three consecutive separations of cleavage products of a human immunoglobulin L-chain with BNPSskatole of varying purity. Column dimensions: $5 \times 100 \mathrm{~cm}$; flow rate: $40 \mathrm{ml} / \mathrm{h}$; eluent: aqueous acetic acid $(50 \mathrm{~g} / 1)$; fraction volume: $15 \mathrm{ml}$ per tube.

Ninhydrin reaction was performed with $100 \mu$ l-aliquots from each tube and the resulting absorbance was measured at $578 \mathrm{~nm}$.

$0-0$ elution curve after cleavage with commercial product 1

- - elution curve after cleavage with commercial product II

$\Delta-\Delta$ elution curve after cleavage with BNPS-skatole prepared in the described manner.

and processed analogously to "method I". The residue from the benzene eluate (about $150 \mathrm{ml}$ ) was dissolved in $5 \mathrm{ml}$ of benzene, stirred with $20 \mathrm{ml}$ of petroleum ether and filtered. The yellow crystalline precipitate was dried in vacuo at $40^{\circ} \mathrm{C}$ (yield: $91.2 \%$ and $81.7 \%$, respectively). Skatole and NPS-skatole were no longer evident in the chromatographic control.

\section{Preparation method III}

$8.4 \mathrm{~g}$ ( $30 \mathrm{mmol}$ ) of NPS-skatole in $300 \mathrm{ml}$ of glacial acetic acid were stirred for 20 minutes at $20^{\circ} \mathrm{C}$ with $8.1 \mathrm{~g}(45 \mathrm{mmol})$ of $\mathrm{N}$-bromosuccinimide (crystallized twice from nitroethane), then mixed with the double volume of water and the mixture extracted immediately three times with $100 \mathrm{ml}$ of benzene in each case. The residue from the combined benzene extracts, washed with $250 \mathrm{ml}$ of water, was dissolved in $100 \mathrm{ml}$ of benzene and the solution evaporated in vacuo $\left(30^{\circ} \mathrm{C}\right)$. The oily BNPS-skatole was dissolved in $10 \mathrm{ml}$ of benzene and purified by means of column chromatography (column dimension $20 \times 1000 \mathrm{~mm}$; gel bed $150 \mathrm{~mm}$ of silica gel/ $30-70$ mesh; benzene as eluant). The benzene was distilled off from the pale yellow eluate (ca. $200 \mathrm{ml}$ ), the oily residue stirred with $50 \mathrm{ml}$ of petroleum ether (b. p. $50-70^{\circ} \mathrm{C}$ ) and the pale yellow crystals, after filtering, dried in vacuo at $25^{\circ} \mathrm{C}$. Yield: $10.51 \mathrm{~g}(98.2 \%)$. The BNPS-skatole obtained in this way is uniform in thin layer chromatography; m. p. $98-106^{\circ} \mathrm{C}$. Re-chromatography on silica gel (gìain size $0.05-0.2 \mathrm{~mm}$ ) was effected with quantitative yield. BNPS-skatole can be crystallized from a 130-fold quantity of petroleum ether (yield $91.5 \%$ ) as well as by dissolving in a 1.5 -fold quantity of anhydrous boiling benzene and mixing with a 24-fold quantity of boiling petroleum ether (yield $93.6 \%$ ). M. p. $99-107.5^{\circ} \mathrm{C}$. BNPS-skatole is hardly soluble in $500 \mathrm{ml} / \mathrm{l}$ acetic.acid but dissolves easily in glacial acetic acid.

\section{Protein cleavage}

For cleavage of tryptophan in proteins the same volumes of the solution of the investigated proteins $\left(M_{r} 20,000-38,000\right.$; $100 \mathrm{mg}$ protein per $5 \mathrm{ml}$ solution) (20) in aqueous acetic acid $(500 \mathrm{~g} / 1$ glacial acetic acid) and of BNPS-skatole $(10-50$-fold excess) in glacial acetic acid were incubated at $20^{\circ} \mathrm{C}$ whilst stirring for 24-48 hours. The phenol concentration (16) was $0.05-0.1$ of the protcin amount. After addition of $100 \mu \mathrm{l}$ of 2-mercaptoethanol (protection of cysteine and methionine) the solution was diluted to the fivefold volume with water and then extracted twice with $5 \mathrm{ml}$ of ethyl ace tate. The aqueous phase was scparated after centrifuging and then lyophilized. The residue was dissolved in $0.1 \mathrm{~mol} / 1$ acetic acid and filtered through Sephadex G-10. After lyophilizing of the colourless eluate, the peptides were separated from unsplit material by means of column chromatography (fig. 1) on Sephadex or Bio$\mathrm{Gel}$ and the peak area measured by in tegration (table 1).

Tab. 1. Yields of fragments (about 34,66 and 114 amino acids, respectively) after cleavage of a homogeneous human (22) immunoglobulin (kappa-chain; $M_{r} 22500$ ) at the tryptophan positions (-trp-leu-ala-trp-tyr-; -glu-trp-lys-) with BNPS-skatole of varying purity. 142

With the commercial product II no cleavage could be demonstrated, but the investigated protein showed a brownish-yellow colour after the reaction.

\begin{tabular}{lll}
\hline BNPS-skatole used & $\begin{array}{l}\text { Amount } \\
\text { of protein }\end{array}$ & $\begin{array}{l}\text { Yield } \\
\text { of fragments }\end{array}$ \\
\hline Commercial; I & $200 \mathrm{mg}$ & $83 \mathrm{mg} \mathrm{(41.5 \% )}$ \\
Commercial; II & $200 \mathrm{mg}$ & - \\
Pure & $200 \mathrm{mg}$ & $145 \mathrm{mg} \mathrm{(72.5 \% )}$ \\
\hline
\end{tabular}

\section{Results and Discussion}

According to our experience the quality and quantity of the protein cleavage at tryptophan positions with BNPS-skatole are far less dependent on its time of storage than on the purity of the starting materials employed for the BNPS-skatole synthesis and on the reaction conditions. Both requirements have been only insufficiently fulfilled in the methods published so far. Contrary to the statements by Fontana (13) it is thus not possible, following the reaction of skatole with 2-nitrophenylsulfenyl chloride, to separate the NPSskatole obtained from the reaction mixture from the numerous, in part coloured impurities via crystallization from aqueous acetic acid; the thin layer chromatographic investigations (fig. 2) showed seven other components besides NPS-skatole. On repeated washing of the dark brown crude product (see "Materials and Methods") with acetic acid, yellow NPS-skatole was in fact obtained as a residue, but the losses involved in this method of purification are too great, due to the solubility of NPS-skatole in glacial acetic acid. Using the method described here for the synthesis and purification, the NPS-skatole, whose m. p. is some $17^{\circ} \mathrm{C}$ above that of the product described by Fontana et al. $(13,19)$, is obtained in almost quantitative yield and in pure form, whilst all spectroscopic data correspond to expectation. 


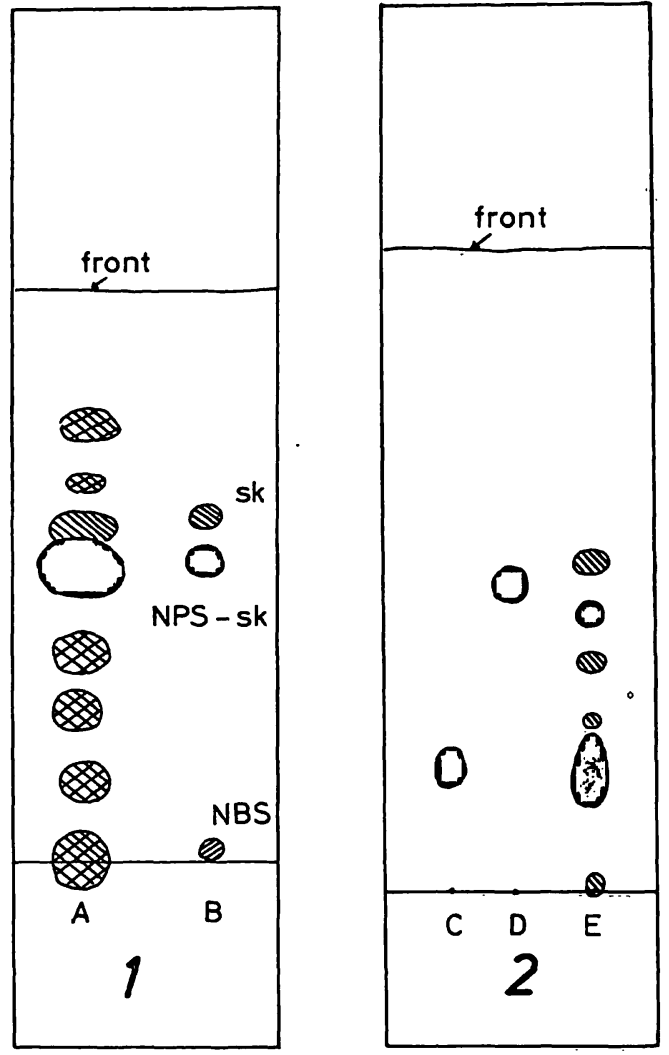

Fig. 2. Thin layer chromatography of 2-(2'-Nitrophenylsulfenyl)= 3-methylindole (NPS-skatole) and of 2-(2'-Nitrophenylsulfenyl)-3-methyl-3-bromoindolenine (BNPS-skatole). (1A): NPS-skatole, fraction I (see "Materials and Methods");

(1B): references $(\mathrm{NBS}=\mathrm{N}$-bromosuccinimide; NPS-sk = NPS-skatole; sk = skatole);

(2C): BNPS-skatole;

(2D): NPS-skatole;

(2E): BNPS-skatole, commercial product (m. p. $88-99^{\circ} \mathrm{C}$ ).

Layer: silica gel with fluorescent indicator; uv detection at $254 \mathrm{~nm}$; solvent: benzene/ligroin, volumes $3+1$.

For the purification of the N-bromosuccinimide required for brominating the NPS-skatole, crystallization from water seemed to us unsatisfactory, since N-bromosuccinimide is partly decomposed by hot water, bromine being set free. Petroleum ether, dichloroethane, chloroform, tetrahydrofurane and dioxan also proved to be unsuitable for the crystallization; whilst the solution in chloroform becomes brown-red on standing, the brown colour which appears suddenly after some minutes on heating $\mathrm{N}$-bromosuccinimide in tetrahydrofuran or dioxan, disappears again after a short time. In anhydrous carbon tetrachloride, benzene or nitroethane on the other hand, no bromine is split off from the $\mathrm{N}$-bromosuccinimide.

Since the equimolar reaction (13) of NPS-skatole with $\mathrm{N}$-bromosuccinimide is not quantitative, the statement by Fontana (13) to the effect that BNPS-skatole produced according to this method is uniform in the thin layer chromatography (silica gel; chloroform as eluant) after a single crystallization must appear doubtful, particularly since impure BNPS-skatole does not precipitate in a crystalline form from petroleum ether but as oil, and according to our experience chloroform is little suited for the chromatographic control. As we have shown, the bromination of NPS-skatole only occurs quantitatively when excess $\mathrm{N}$-bromosuccinimide is used. On account of the difficulty of dissolving $\mathrm{N}$-bromosuccinimide in aromatic hydrocarbons we found it more favourable to use benzene, in which BNPS-skatole dissolves easily, in place of ether for extracting the BNPS-skatole from the reaction mixtures. After column chromatography on silica gel we obtained from the benzene extract (which should be separated as quickly as possible from the aqueous phase in order to reduce decomposition) a pale yellow crystallized BNPS-skatole (yield $>95 \%$ ) which was uniform in thin layer chromatography and which, in contrast to Fontana (13) and Omerin et al. (12), showed after crystallization no decomposition on melting. If pure BNPS-skatole is stored at temperatures under $-25^{\circ} \mathrm{C}$ (if possible at about $-70^{\circ} \mathrm{C}$ ), away from light, the chromatographic control shows no sign of decomposition, even after months.

\section{Spectroscopic investigations}

The mass, ultraviolet, infrared and proton NMR spectra do not enable a clear-cut differentiation between the postulated 3-bromo-3-methyl-indolenine and the theoretically equally possible N-bromo-3-methylindole structures for BNPS-skatole. However, proof for one of the two structures should be obtained from the position of the signals in ${ }^{13} \mathrm{C}$ NMR spectroscopy, since the quaternary C-3 in the case of the indolenine structure is, in contrast to the indole structure, not involved in a double bond (formula V).

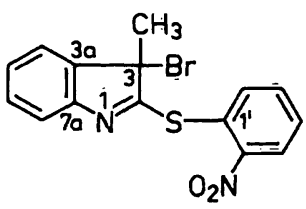

(V)

Mass spectra

Apart from the molecular weight peaks (NPS-skatole: $\mathrm{M}_{\mathrm{r}}=284$, $\mathrm{M}_{\mathrm{r}}+\mathrm{H}^{+}=285$; BNPS-skatole: $\mathrm{M}_{\mathrm{r}}=363, \mathrm{M}_{\mathrm{r}}-\mathrm{H}^{+}=362$,

$\left.\mathrm{M}_{\mathrm{r}}+\mathrm{H}^{+}=364\right)$ and the NPS-skatole peak in the BNPS-skatole spectrum (splitting off of the labile bromine), both mass spectra contain a series of intensive peaks which for the most part are common to both compounds and which point to interesting fragmentation reactions. Their explanation is the aim of a further investigation (21).

\section{Infrared spectra}

The two strong bands of the aromatic nitro group are at $1350 \mathrm{~cm}^{-1}$, symmetric stretch, and at $1510 \mathrm{~cm}^{-1}$, asymmetric stretch, respectively. The characteristic absorption for the aromatic ortho-substitution (four neighbouring $\mathrm{H}$-atoms) occurs in both spectra at $770 \mathrm{~cm}^{-1}$. The NH-stretch vibration. (NPS-skatole) is at $3360 \mathrm{~cm}^{-1}$. Since $\mathrm{KBr}$ is not suitable for BNPS-skatole in this region, no statement concerning the ring nitrogen can be made. In the case of the indole derivatives examined by us, common bands occur at $740 \mathrm{~cm}^{-1}$ (NPSskatole $738 \mathrm{~cm}^{-1}$; BNPS-skatole $742 \mathrm{~cm}^{-1}$; skatole $745 \mathrm{~cm}^{-1}$ ) and at $1300 \mathrm{~cm}^{-1}$. The sharp bands at $855 \mathrm{~cm}^{-1}$ (BNPSskatole > NPS-skatole), at $1560 \mathrm{~cm}^{-1}$ and at $1.580 \mathrm{~cm}^{-1}$ are missing in the skatole spectrum. The asymmetric $\mathrm{C}-\mathrm{CH}_{3}$ deformation vibration occurs at $1450 \mathrm{~cm}^{-1}$ for skatole, NPSskatole and BNPS-skatole; the weaker symmetric vibration is 
at $1380 \mathrm{~cm}^{-1}$. With BNPS-skatole, near the nitro double band $\left(1510 \mathrm{~cm}^{-1}, 1515 \mathrm{~cm}^{-1}\right)$ there is a strong absorption at $1525 \mathrm{~cm}^{-1}$ which in the case of similarly-substituted $2,3,3-$ trimethylindolenine appeared displaced towards shorter wavelengths (at $1565 \mathrm{~cm}^{-1}$ ) and is missing in the spectra of skatole, NPS-skatole, 2, 3-dimethylindole and 2, 3, 5-trimethylindole. We assume that the $\mathrm{C}=\mathrm{N}$ stretch vibration appearing in the indolenine structure is concerned here.

Ultraviolet spectra

See Table 2.

Tab. 2. Ultraviolet spectra of NPS-skatole $(42.9 \mu \mathrm{mol} / \mathrm{l})$ and of BNPS-skatole $(34.7 \mu \mathrm{mol} / 1$ and $34.0 \mu \mathrm{mol} / \mathrm{l}$, respectively) in ethanol (for fluorescence spectroscopy) and in $n$-heptane, respectively. (s) $=$ shoulder

\begin{tabular}{lcccc}
\hline & Solvent & $\begin{array}{c}\text { Absorption } \\
\lambda_{\max }[\mathrm{nm}]\end{array}$ & A & $\begin{array}{l}\epsilon \\
{\left[\mathrm{mol}^{-1}\right.} \\
\left.1 \cdot \mathrm{cm}^{-1}\right]\end{array}$ \\
\hline NPS-skatole & ethanol & ca. $209(\mathrm{~s})$ & & \\
& & 224 & 1.965 & 45,802 \\
& & 281.5 & 0.830 & 19,347 \\
BNPS-skatole & 360 & 0.305 & 7,109 \\
& \multirow{2}{*}{ ethanol } & 205.5 & 0.875 & 25,220 \\
& & 239 & 0.820 & 23,635 \\
& & ca. 328 & 0.260 & 7,494 \\
& heptane & 199.5 & 0.950 & 27,936 \\
& & 236 & 0.855 & 25,142 \\
& & ca. 345 & 0.290 & 8,528 \\
\hline
\end{tabular}

Tab. 3. Proton-NMR spectra of NPS-skatole and of BNPSskatole. Solvent: $\mathrm{CDCl}_{3}$; sweep time: $500 \mathrm{~s}$; sweep width: $1000 \mathrm{~Hz}$; lock signal: TMS.

\begin{tabular}{lll}
\hline Proton & $\begin{array}{l}\text { NPS-skatole } \\
\text { ppm }\end{array}$ & $\begin{array}{l}\text { BNPS-skatole } \\
\text { ppm }\end{array}$ \\
\hline Methyl & 2.39 & 2.08 \\
-NH & 8.05 & - \\
C-3' & 8.2 & \} 8.09 \\
C-7 & 6.7 & \\
C-4, C-5, C-6, & $7.1-7.4 ;$ & \} 7.1-7.7 \\
C-4', C-5, C-6' & 7.6 & \\
\hline
\end{tabular}

Tab. 4. ${ }^{13} \mathrm{C}$ NMR spectrum $(22.63 \mathrm{MHz})$ of BNPS-skatole. Normal, unexpanded spectrum; lock signal: TMS (quartet); sweep width: $6024 \mathrm{~Hz}$; solvent: $\mathrm{CDCl}_{3}$.

\begin{tabular}{ll}
\hline${ }^{13} \mathrm{C}$ & ppm \\
\hline Methyl (quartet) & 27.8 \\
$\mathrm{C}-3 \quad$ (singlet) & 60.6 \\
$(\mathrm{CDCl})_{3}$ & $(77.1)$ \\
$\mathrm{C}-4, \mathrm{C}-5, \mathrm{C}-6, \mathrm{C}-7$ & $120.2 ; 122.6 ; 125.6 ; 126.3 ;$ \\
$\mathrm{C}-3^{\prime}, \mathrm{C}-4^{\prime}, \mathrm{C}-5^{\prime}, \mathrm{C}-6^{\prime}$ & $129.7 ; 130.0 ; 133.1 ; 136.4$ \\
$\mathrm{C}-7 \mathrm{a} ; \mathrm{C}-3 \mathrm{a}$ & $133 ; 124.9$ \\
$\mathrm{C}-2^{\prime} \quad$ (singlet) & 141.5 \\
$\mathrm{C}-1^{\prime} \quad$ (singlet) & 151.2 \\
$\mathrm{C}-2 \quad$ (singlet) & 180.3 \\
\hline
\end{tabular}

\section{Proton NMR spectra}

Whilst the signal for -NH (sec Table 3) is clearly marked for NPS-skatole, a sign for a bromine situated on the ring nitrogen is not identifiable in the BNPS-skatole spectrum. Differentiation between $>\mathrm{N}-\mathrm{Br}$ and the indolenine structure $(-\mathrm{N}=)$ is therefore not possible.

\section{${ }^{13}$ C NMR spectra}

A quartet is to be expected for the methyl group bound at $\mathrm{C}-3$ and a singlet for the quaternary C-3. Whilst the singlet for the $\mathrm{C}-3$ in compounds having an indole structure lies at ppmvalues $>100$, it is strongly displaced in BNPS-skatole (see Table 4) at $60.6 \mathrm{ppm}$, and indicates a C-3 that is not involved in a double bond. For this reason BNPS-skatole must be acknowledged as having the indolenine structure.

\section{Protein cleavage}

The yield of the protein cleavage at tryptophan positions with BNPS-skatole was determined by comparing the ratio of the sum of the fragments to unsplit starting material. This showed a yield of $60-85 \%$ (22) when using BNPS-skatole prepared in the described manner, whilst the yields when using purchaseable preparations were considerably lower $(0 \%-40 \%)$. The occurrence of yellow-brown coloured peptide fragments, that are sometimes observed when using impure BNPS-skatole (table 1), could also be avoided by using pure BNPS-skatole.

\section{Acknowledgements}

For the recording of the mass spectra and the proton- and ${ }_{13} \mathrm{C}$ NMR spectra I thank Miss I. Buhrow and Miss G. Schild; for the discussion of these spectra Dr. W. Schäfer and Dr. J. Sonnenbichler, Max-Planck-Institut für Biochemie, D-8033 Martinsried bei München.

\section{References}

1. Witkop, B. (1961), Adv. Protein Chem. 16, 261-321.

2. Ramachandran, L. K. \& Witkop, B. (1967), in: Methods in Enzymology (Hirs, C. H. W., ed.), Vol. 11, 283-299, Academic Press, New York.

3. Witkop, B. \& Ramachandran, L. K. (1964), Metab. Clin. Exp. İ 1016-1021.

4. Ramachandran, L. K. (1962), J. Sci. Res. (Hardwar India) $21 C, 111-117$

5. Han, K., Dautrevaux, M. \& Biserte, G. (1966), Ann. Pharm. Fr. 24, 649-662.

6. Stelakatos, G. C. (1962), Chim. Chronika (Athens, Greece) $27 A, 10 \hat{7}-114$

7. Spande, T. F. \& Witkop, B. (1967), in: Methods in Enżymology (Hịs, C. H. W., ed.), Vol. 11, p. 506, Academic Press, New York.

8. Kronman, M. J., Robbins, F. M. \& Andreotti, R. E. (1967), Biochim. Biophys. Acta 147, 462-472.

9. Eylar, E. H. \& Hashim, G. A. (1969), Arch. Biochem. Biophys. 131, 215-222.

10. Burstein, Y., Wilchek, M. \& Patchornik, A. (1967), Isr. J. Chem. 5, 658.

11. Kingsbury, W. D. \& Johnson, C. R. (1972) Tetrahydron Lett., 501.

12. Omenn, G. S., Fontana, A. \& Anfinsen, Chr. B. (1970), J. Biol. Chem. 245, 1895-1902.

13. Fontana, A. (1972), in: Methods in Enzymology (Hirs, C. H. W., ed.), Vol. 25, 419-423, Academic Press, New York.

14. Patchornik, A., Lawson, W. B. \& Witkop, B. (1958), J. Am. Chem. Soc. $80,4747-4748$. 
15. Spande, T. F., Witkop, B., Degani, Y. \& Patchornik, A. (1970), Adv. Protein Chem. 24, 97-260.

16. Fontana, A., Vita, C. \& Toniolo, C. (1973), FEBS Letters $32,139-142$.

17. Burnett, P. R. \& Eylar, E. H. (1971), J. Biol. Chem. 246, 3425-3430.

18. Bergstrand, H. (1971), Eur. J. Biochem. 21, 116-124.
19. Fontana, A., Marchiori, F., Rocchi, R. \& Pajetta, P. (1966), Gazz. Chim. I tal. 96, 1301-1312.

20. Kreutzer, M., Schmidt, M., Stadiler, E. \& Żeitler, H. J.

(1977), Hoppe-Seyler's Z. Physiol. Chem. 358, 1081-1091.

21. Zeitler, H. J. \& Schäfer, W., in prep. (1978).

22. Eulitz, M., Kley, P. \& Zeitler, H. J. (1978), Hoppe-Seyler's Z. Physiol Chem., in prep.

Dr. Hans-Jörg Zeitler Institut für Hämatologie der Gesellschaft für Strahlen- und Umweltforschung m.b.H. Landwehrstraße 61

D-8000 München 2 